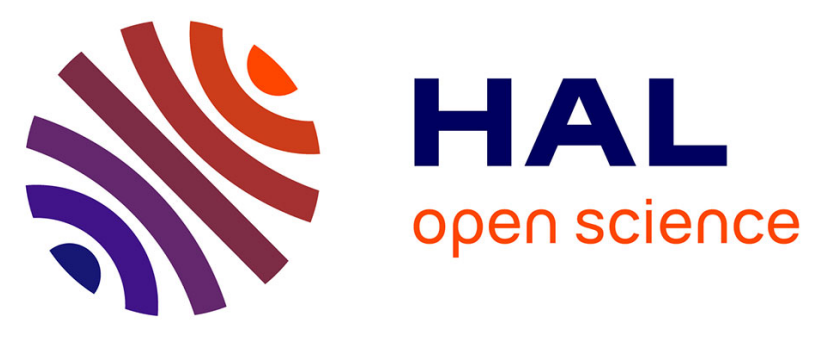

\title{
Resveratrol in human hepatoma HepG2 cells: metabolism and inducibility of detoxifying enzymes.
}

Allan Lançon, Nathalie Hanet, Brigitte Jannin, Dominique Delmas, Jean-Marie Heydel, Gérard Lizard, Marie-Christine Chagnon, Yves Artur, Norbert Latruffe

\section{To cite this version:}

Allan Lançon, Nathalie Hanet, Brigitte Jannin, Dominique Delmas, Jean-Marie Heydel, et al.. Resveratrol in human hepatoma HepG2 cells: metabolism and inducibility of detoxifying enzymes.. Drug Metabolism and Disposition, 2007, 35 (5), pp.699-703. 10.1124/dmd.106.013664 • hal-00259260

\section{HAL Id: hal-00259260 https://hal.science/hal-00259260}

Submitted on 13 Mar 2008

HAL is a multi-disciplinary open access archive for the deposit and dissemination of scientific research documents, whether they are published or not. The documents may come from teaching and research institutions in France or abroad, or from public or private research centers.
L'archive ouverte pluridisciplinaire HAL, est destinée au dépôt et à la diffusion de documents scientifiques de niveau recherche, publiés ou non, émanant des établissements d'enseignement et de recherche français ou étrangers, des laboratoires publics ou privés. 


\title{
RESVERATROL IN HUMAN HEPATOMA HEPG2 CELLS: METABOLISM AND INDUCIBILITY OF DETOXIFYING ENZYMES
}

\author{
Allan Lançon ${ }^{1}$, Nathalie Hanet ${ }^{2}$, Brigitte Jannin ${ }^{1}$, Dominique Delmas ${ }^{1}$, Jean-Marie \\ Heydel $^{2}$, Gérard Lizard ${ }^{1}$, Marie-Christine Chagnon ${ }^{2}$, Yves Artur ${ }^{2}$ and Norbert Latruffe ${ }^{1}$ \\ ${ }^{1}$ Biochimie Métabolique et Nutritionnelle - Université de Bourgogne \\ Faculté des Sciences et Centre de Recherche INSERM U866, Dijon, France \\ ${ }^{2}$ Unité Mixte de Recherche 1234 Toxicologie Alimentaire \\ Institut National de la Recherche Agronomique-Université de Bourgogne, Dijon, France
}

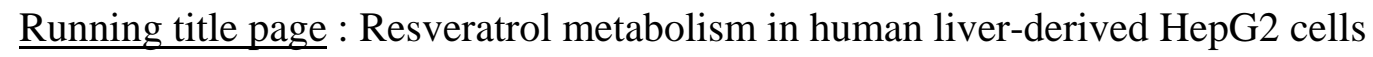

Abbreviations: HPLC, high-performance liquid chromatography; APCI-MS: atmospheric pressure chemical ionization-mass spectrometry; UGT: uridine diphosphate glucuronosyltransferase; ST: sulfotransferase; MDR: multi-drug resistance; MRP: multi-drug resistance-associated protein; RT-PCR: reverse transcriptase polymerase chain reaction.

\begin{abstract}
trans-Resveratrol is a polyphenol present in several plant species. Its chemopreventive properties against several diseases have been largely documented. To validate a model for the study of the factors influencing its biological fate at the hepatic level, the metabolism and the efflux of resveratrol were studied in the human hepatoblastoma cell line, HepG2. Comparative high-performance liquid chromatography analysis of cell culture media before and after deconjugation showed that resveratrol was rapidly conjugated; at the concentration of $10 \mu \mathrm{M}$, it was entirely metabolized at $8 \mathrm{~h}$ of incubation. Two main resveratrol metabolites, monosulfate and disulfate, were identified by atmospheric pressure chemical ionization-mass spectrometry, thanks to their quasi-molecular ion and their characteristic fragmentation. To correlate with the auto-induction of resveratrol metabolism evidenced in HepG2 cells after a pretreatment for $48 \mathrm{~h}$ with 10 _M resveratrol, the inducibility of phase II enzymes by resveratrol was studied by real-time quantitative reverse transcriptase-polymerase chain reaction and flow cytometry. Observed, in particular, were an increase in mRNA expression levels of three metabolizing enzymes, two isoforms of UDPglucuronosyltransferases, UGT1A1 and UGT2B7 (5-fold increased), and a sulfotransferase, ST1E1, in cells pretreated for $24 \mathrm{~h}$ with $10 \mu \mathrm{M}$ resveratrol. These results were correlated with an increase in protein expression, especially after $48 \mathrm{~h}$ of treatment. On the other hand, the intracellular resveratrol retention in cells treated with MK571 (3-[[3-[2-(7-chloroquinolin-2-yl)vinyl]phenyl]-(2-dimethylcarbamoylethylsulfanyl)methylsulfanyl] propionic acid), a multidrug resistance-associated protein inhibitor, strongly suggests the involvement of this $A B C$ transporter family in the efflux of resveratrol conjugates from human liver.
\end{abstract}

Trans-resveratrol (trans-3,5,4'-trihydroxystilbene, fig. 1) is a natural molecule present in several vegetal sources. Its name refers to Veratrum grandiflorum, one of these sources. Resveratrol is also present in root preparations of Polygonum cuspidatum, which were used in traditional Chinese and Japanese medicines, so-called "Hu-Chang" and "Ko-jo-kon" respectively. The potential resveratrol benefits for health have led to many reports. Resveratrol may have particularly chemopreventive effects against cardiovascular diseases and ageing (for a review, see Delmas et al., 2005). It may have also chemopreventive and therapeutic properties for fighting cancer (for a review, see Delmas et al., 2006). A good knowledge of bioavailability is necessary to assess the benefits of resveratrol dietary consumption and/or resveratrol supplementation. Several studies have been reported about 
metabolism and bioavailability of resveratrol in the last 5 years (for a review, see Wenzel and Somoza, 2005). Transport mechanism in human intestine was studied in Caco-2 model (Kaldas et al., 2003). In humans, it was shown that ${ }^{14} \mathrm{C}$ - resveratrol is rapidly absorbed after oral consumption. The highest plasma concentrations are reached between 30 and $60 \mathrm{~min}$ after ingestion, with the appearance of new resveratrol plasma peak $6 \mathrm{~h}$ after oral consumption. This second peak suggests the involvement of enterohepatic recirculation of conjugated metabolites by reabsorption after intestinal hydrolysis of conjugates (Walle et al., 2004), already evidenced by Marier et al. (2002) in a linked-rat model.

Our purpose was to validate the HepG2 cell line as a model for the study of the human hepatic metabolism of resveratrol. Indeed, liver constitutes an important step before the distribution of resveratrol to tissues and it is probably exposed again to resveratrol during enterohepatic recirculation, so that it plays a pivotal role in resveratrol disposition. We have already reported that hepatic uptake of resveratrol occurs according both passive diffusion and facilitated processes (Lançon et al., 2004). In the present study, we showed by HPLC analysis of culture media after deconjugation that resveratrol was rapidly conjugated and eliminated from the HepG2 cells. Metabolites were identified by mass spectrometry. Moreover, we have found that like other dietary compounds resveratrol can induce some phase II enzymes. Finally, a transport study with labeled resveratrol strongly suggested the involvement of multi-drug transporters in the efflux of conjugated resveratrol.

\section{METHODS}

Chemicals. Trans-resveratrol, carbamazepin and $\beta$-glucuronidase (type HP-2) were purchased from Sigma (St. Louis, MO, USA). MK571 was purchased from Alexis (San Diego, CA, USA). [ ${ }^{3} \mathrm{H}$ ]-trans-resveratrol (specific activity: $74 \mathrm{GBq} / \mathrm{mmol}$ ) labeled in ortho and para of phenol groups was prepared for us by Amersham Pharmacia Biotech (Little Chalfont, Buckinghamshire, UK).

Cell Culture and resveratrol treatments. The HepG2 cell line obtained from the European Collection of Cell Cultures was cultured in a phenol red-free DME medium supplemented with 1\% glutamine, 1\% non-essential L-aminoacids (Sigma) and 10\% fetal bovine serum FBS (Gibco). Resveratrol was dissolved in ethanol; control and treated cells received the same final concentration of ethanol (0.1\%). For RT-PCR experiments, cells were harvested at the same time and total RNA was prepared using Trizol Reagent (Invitrogen, Life technologies, France) according to the manufacturer's instructions.

Deconjugation procedure and solid-phase extraction. Samples $(0.5 \mathrm{ml})$ of cell culture media were treated for $2 \mathrm{~h}$ at $37^{\circ} \mathrm{C}$ with $200 \mathrm{U} \beta$-glucuronidase in $0.5 \mathrm{ml}$ of $0.2 \mathrm{M}$ acetate buffer; control samples were incubated with buffer alone. Each sample was then acidified to $\mathrm{pH}$ 4.5, received carbamazepin as internal standard (Zhu et al. 1999) and was passed through a C18 Sep-Pak cartridge (Waters, Milford, MA, USA) pre-conditioned with methanol and acetate buffer. After washing with acetate buffer, resveratrol and/or its metabolites were eluted with $2 \mathrm{ml}$ of methanol. After evaporation, they were redissolved in ethanol for analysis.

HPLC analysis. Resveratrol assays were performed on a reverse-phase Nucleosil C18 column $(250 \times 4,6 \mathrm{~mm}, 5 \mu \mathrm{m})$ from Altech in a Waters 625-LC system. Compounds were eluted from the column with a gradient containing water and acetonitrile. Solvents were delivered according to Adrian et al. (2000). The UV detector (Waters 486) was set at $306 \mathrm{~nm}$. Resveratrol amounts were quantified with a SP4400 ChromJet integrator (Spectra-Physics).

Mass spectrometry analysis. Resveratrol incubations (30 $\mathrm{MM}$ for $10 \mathrm{~h}$ ) were performed in medium containing only $1 \%$ serum to minimize background due to serum constituents. Continuous infusion was performed on an Esquire mass spectrometer (Bruker Daltonik, Bremen, Germany) equipped with an ion-trap analyzer, APCI source and Bruker Daltonics Esquire LC4.5 data analysis software. Calibration of the mass spectrometer was achieved by injection of resveratrol. Spectra were recorded in the negative ion mode. 
Quantitative Real-time PCR. SYBR Green PCR Mix (Biorad) and the iCycler thermocycler (Biorad) were used to detect the real-time quantitative PCR products of reversetranscribed cDNA samples according to the manufacturer's instructions. The incubation conditions were as follows: $95^{\circ} \mathrm{C}$ for $3 \mathrm{~min}$, followed by 40 cycles $\left(95^{\circ} \mathrm{C}\right.$ for 15 sec., $60^{\circ} \mathrm{C}$ annealing for $1 \mathrm{mn}$ ). Expression levels of human phase II enzymes and housekeeping genes, $\beta 2$ microglobulin, glyceraldehyde-3-phosphate dehydrogenase and porphobilinogen deaminase mRNAs were determined by using specific primers (Congiu et al., 2002). The Relative Expression Software Tool - Multiple Condition Solver (REST-MCS (C)- version 2) was used to calculate the relative expression of target genes mRNA in real-time PCR using Pair Wise Fixed Reallocation Randomization Test $\subseteq$ (Pfaffl et al., 2002). The mathematical model used is based on the mean crossing point deviation between sample and control group of target gene, normalized by the mean crossing point deviation of reference genes. Specific amplification efficiencies are included in the correction of the quantification ratio. Results are expressed as means \pm standard error (SE) from duplicate PCR determinations of triplicate sixwell plates from three independent experiments for each set of conditions tested. Significant differences between groups were analyzed by using REST-MC@ test with 2000 randomization iterations.

Flow cytometry analyses. HepG2 cells were seeded into six-well plates at 500,000 per well. They were treated $24 \mathrm{~h}$ after seeding with resveratrol for 24 or $48 \mathrm{~h}$. They were subsequently treated as previously described (Delmas et al., 2003). The used primary antibodies were mouse anti-ST1E1 (Calbiochem, VWR international SAS), mouse antiUGT1A1, mouse anti-UGT2B7 (Gentest, BD Biosciences) or isotype-matched controls (Jackson ImmunoResearch Laboratories, West Grove, PA, USA). The second antibody was a fluorescein isothiocyanate-labeled anti-mouse IgG (Jackson ImmunoResearch Laboratories) Simultaneously, a non-relevant isotype-matching Ab was used as negative control. Analyses were performed on a logarithmic scale consisting of 4 decades of log on a GALAXY cytometer (Partec, Münster, Germany) at excitation and emission wavelengths of $488 \mathrm{~nm}$ and $590 \mathrm{~nm}$, respectively. For each sample, 10,000 cells were acquired with the FlowMax software (Partec), and data registered under the fcs format were further analyzed with Expo 32 software (Beckman-Coulter, Miami, USA).

Tritiated resveratrol uptake measurement. HepG2 cells were incubated at $37^{\circ} \mathrm{C}$ with 1 $\mu \mathrm{M}$ of tritiated resveratrol, with or without $50 \mu \mathrm{M}$ of MK571. The labeled medium was removed and the cell wells were washed two times with a cold PBS buffer. After addition of $400 \mu \mathrm{l}$ per well of lysis buffer ( $0.1 \%$ SDS, $\left.0.1 \mathrm{M} \mathrm{NaOH}, 2 \% \mathrm{Na}_{2} \mathrm{CO}_{3}\right)$, the cell homogenates were transferred into flasks and cell-associated radioactivity was counted in a Flow Scintillation Analyzer Perkin-Elmer (Life Sciences Inc., Welleley, MA, USA). Data were analyzed with a Varian Star chromatography workstation software version 5.5.

\section{RESULTS AND DISCUSSION}

Resveratrol metabolism: time-course and autoinduction. HepG2 cells were incubated with $10 \mu \mathrm{M}$ of resveratrol for different times. Cell culture media were then collected, treated or not with $\beta$-glucuronidase, extracted and analyzed by HPLC (Fig. 1B). The amount of resveratrol conjugated and released in the medium was indirectly determined by difference between untreated media (unconjugated resveratrol) and enzyme-treated media (total). The proportion of conjugated resveratrol was of $20 \%$ after $2 \mathrm{~h}$ of incubation, increased to $50 \%$ at $4 \mathrm{~h}$ and reached almost $100 \%$ at $8 \mathrm{~h}$. Moreover the initial amounts of resveratrol were always recovered after enzymatic treatment, meaning that there were no other metabolites than glucuronides and/or sulfates (the $\beta$-glucuronidase used for these experiments having also a sulfatase activity).

To search for a possible inducibility of phase II enzymes by resveratrol, we studied the effect of a pre-treatment of the cells with resveratrol on its own metabolism. For this purpose, cells were pre-treated either with $10 \mu \mathrm{M}$ resveratrol for 2-fold $24 \mathrm{~h}$ (T48) or only for the last $24 \mathrm{~h}$ (T24) or cultured for $48 \mathrm{~h}$ without resveratrol (T0). After these $48 \mathrm{~h}$, the cells were 
incubated again with $10 \mu \mathrm{M}$ resveratrol. Unconjugated resveratrol remaining in the media after $2 \mathrm{~h}$ or $4 \mathrm{~h}$ of incubation was quantified by HPLC (Fig. 1C). The percentage of unconjugated resveratrol was significantly lower in cells pre-treated for $48 \mathrm{~h}$; it fell from $45 \%$ to $30 \%$ after $2 \mathrm{~h}$ incubation and from $16 \%$ to $8 \%$ after $4 \mathrm{~h}$ incubation. These decreases expressed an acute resveratrol metabolism in cells pre-treated for $48 \mathrm{~h}$ with resveratrol and consequently corresponded to an autoinduction of this metabolism.

Ion-trap mass spectrometry analysis of resveratrol metabolites. We performed an analysis of extracted cell culture media by direct infusion to allow not only the determination of metabolite class but also the discrimination between mono- and di-derivatives as well as mixed derivatives. Five compounds were found only in the media of resveratrol-treated cells and identified thanks to their characteristic fragmentation (Table I). Unconjugated resveratrol was identified by comparison to standard resveratrol. Resveratrol monosulfate and resveratrol disulfate were identified thanks to the characteristic loss of a fragment of 80 ( $\mathrm{SO}_{3}$ group). Two isomeric forms are a priori possible for the mono-derivative: resveratrol-3-sulfate and resveratrol-4'-sulfate, as well as two isomeric forms for the di-derivative: resveratrol-3,4'disulfate and resveratrol-3,5-disulfate (see formula Fig.1A). These different metabolites were found in plasma of Wistar rats after oral administration of resveratrol Wenzel et al., 2005). Contrary to this study, we have not detected resveratrol-trisulfate in our analysis.

Our results are in accordance with a study on healthy volunteers (Walle et al., 2004), which reported that sulfoconjugates are the main urine excreted metabolites in humans (twice more that the glucuronoconjugates) and that resveratrol conjugation occurs rapidly, mostly as sulfate conjugates, after i.v. resveratrol infusion. Although resveratrol glucuronidation was shown in human liver (De Santi et al., 2000b, Vitaglione et al., 2005), our analysis did not evidence any glucuronide. They were not lost during the solid phase extraction; we have indeed found the same recovery of radioactivity after extraction on SepPak cartridges of media incubated with radiolabeled resveratrol in presence or in absence of cells, meaning that all the metabolites eluted in the methanolic phase (data not shown). We may suggest that in our experimental conditions sulfation was predominant over glucuronidation; resveratrol sulfation was characterized by a smaller $K_{M}(0,63 \mu \mathrm{M}$, De Santi et al., 2000 b) that glucuronidation (150 $\mu \mathrm{M}$, De Santi, 2000a). Therefore, it should exist a competition between the two enzymes for resveratrol metabolism, so that high-affinity sulfation pathway occurs exclusively at moderate resveratrol concentrations, not sufficient to saturate this pathway.

Induction of phase II enzymes. To explain the autoinduction of resveratrol metabolism, we searched for the induction of phase II enzymes. Induction of mRNA levels was determined by quantitative RT-PCR in HepG2 cells pre-treated for $24 \mathrm{~h}$ with variable concentrations of resveratrol. Two UGT isoforms were tested, UGT1A1 and UGT2B7 and one sulfotransferase isoform, ST1E1 (Fig.2A). For these three enzymes, we observed an induction of mRNA level with a maximum for a pre-treatment with $10 \mu \mathrm{M}$ resveratrol. UGT2B7 appeared to be the more induced with a 5-fold increase in mRNA expression after pre-treatment with $10 \mu \mathrm{M}$ resveratrol.

To determine if the induction of their mRNA levels is correlated with an increase in their protein amounts, we measured the expression of UGT1A1, UGT2B7 and ST1E1 in HepG2 cells untreated or treated with 10 or $30 \mu \mathrm{M}$ resveratrol for 24 and $48 \mathrm{~h}$. After treatment, the cells were stained with the appropriate Abs, and then analyzed by flow cytometry (Fig.2B). Resveratrol at $10 \mu \mathrm{M}$ induced a weak increase in UGT2B7 expression at $24 \mathrm{~h}(+11 \%)$. An increase more important was observed at $48 \mathrm{~h}$ with $30 \mu \mathrm{M}(+65 \%)$. Concerning the UGT1A1 expression, we noted $+24 \%$ at $10 \mu \mathrm{M}$ for $24 \mathrm{~h}$ of treatment and $+37 \%$ for $48 \mathrm{~h}$. At $30 \mu \mathrm{M}$ resveratrol, we observed an increase of $25 \%$ at $24 \mathrm{~h}$ and of $29 \%$ at $48 \mathrm{~h}$. We observed also an increase in ST1E1 expression of $49 \%$ at $24 \mathrm{~h}$ and $+14 \%$ at $48 \mathrm{~h}$ with $10 \mu \mathrm{M}$ of resveratrol. and of $14 \%$ at $24 \mathrm{~h}$ and $23 \%$ at $48 \mathrm{~h}$ with $30 \mu \mathrm{M}$ of resveratrol. Therefore, a protein induction was observed for these three enzymes, generally greater after $48 \mathrm{~h}$ of pre-treatment. These results were in accordance with those of RT-PCR: generally, protein induction after $48 \mathrm{~h}$ of 
pre-treatment correlated well with the mRNA level induction after $24 \mathrm{~h}$ of pre-treatment. The induction of ST1E1 correlates well with the autoinduction of resveratrol metabolism, meaning that ST1E1 activity is increased, this isoform being involved in resveratrol sulfation in human liver (Miksits et al., 2005). Moreover, we have found the induction of UGT1A1 responsible for glucuronidation of trans-resveratrol and UGT2B7, which presents an activity, restricted to cis-resveratrol (Aumont et al., 2001). UGT1A1 inducibility was shown in vivo in rat liver, but with treatments at high doses of resveratrol (Hebbar et al., 2005).

Impairment of resveratrol efflux by MRP transport inhibitor. The time-course of resveratrol uptake by HepG2 cells was monitored by the determination of intracellular radioactivity after cell incubations at $37^{\circ} \mathrm{C}$ with $1 \mu \mathrm{M}$ of radiolabeled resveratrol. The various incubation times were chosen according to our previous experiments showing that intracellular radioactivity increases rapidly to reach a maximum at 10 minutes (Lançon et al., 2004). The same fast resveratrol uptake was observed in control cells as well as in cells treated with $50 \mu \mathrm{M}$ MK-57 (Fig.3). Conversely, the decrease in intracellular radioactivity in MK571 treated cells was delayed, compared to control cells. After $1 \mathrm{~h}$ of incubation, the intracellular radioactivity in MK571 treated cells was 2.8-fold higher than in control cells; it was still 2-fold higher after $2 \mathrm{~h}$ of incubation. These experiments indicated that MK571 did not affect resveratrol influx but impaired resveratrol efflux. MK571 being known to inhibit MRPs, our results show for the first time the implication of these pumps in the efflux of conjugated resveratrol from liver. By also using MK571, Henry et al. (2005) have reported the implication of MRP2/MRP3 in human intestinal Caco2 cell line transport of conjugated resveratrol. Moreover, it was shown that resveratrol impairs ochratoxine A intestinal efflux in a similar manner as MK571, suggesting a competitive inhibition of MRP-2 by resveratrol (Sergent et al., 2005). Conversely, we have not shown any effect of verapamil on resveratrol efflux, excluding the implication of the MDR glycoprotein P (data not shown). The inhibition of MRPs by resveratrol may be interesting for chemotherapeutic strategies. Indeed, it has been shown that resveratrol acts in synergy with death receptor ligands and may be a sensitizing agent to chemotherapeutic drugs (Delmas et al., 2004). Therefore, a competitive inhibition of MRP-2 by resveratrol, used in association with cytotoxic drugs, would contribute to reduce therapeutic failures in the treatment of chemoresistant cancers.

\section{ACKNOWLEDGEMENTS}

We acknowledge Etienne Semon for mass spectrometry analysis. 


\section{REFERENCES}

- Adrian M, Jeandet P, Douillet-Breuil AC, Tesson L and Bessis R (2000) Stilbene content of mature Vitis vinifera berries in response to UV-C elicitation. J Agric Food Chem 48:6103-6105.

- Aumont V, Krisa S, Battaglia E, Netter P, Richard T, Merillon JM, Magdalou J and Sabolovic N. (2001) Regioselective and stereospecific glucuronidation of trans- and cis-resveratrol in hum. Arch Biochem Biophys 393:281-289.

- Congiu M, Mashford ML, Slavin JL and Desmond PV (2002) UDP glucuronosyltransferase mRNA levels in human liver disease. Drug Metab Dispos 30:129-134.

- De Santi C, Pietrabissa A, Spisni R, Mosca F and Pacifici GM (2000a) Sulphation of resveratrol, a natural product present in grapes and wine, in the human liver and duodenum. Xenobiotica 30:609-617.

- De Santi C, Pietrabissa A, Mosca F and Pacifici GM (2000b) Glucuronidation of resveratrol, a natural product present in grapes and wine, in the human liver. Xenobiotica 30:1047-1054.

- Delmas D, Rebe C, Lacour S, Filomenko R, Athias A, Gambert P, Cherkaoui-Malki M, Jannin B, Dubrez-Daloz L, Latruffe N and Solary E. (2003) Resveratrol-induced apoptosis is associated with Fas redistribution in the rafts and the formation of a death inducing signaling complex in colon cancer cells. J Biol Chem278:41482-90.

- Delmas D, Rebe C, Micheau O, Athias A, Gambert P, Grazide S, Laurent G, Latruffe N and Solary E (2004) Redistribution of CD95, DR4 and DR5 in rafts accounts for the synergistic toxicity of resveratrol and death receptor ligands in colon carcinoma cells. Oncogene 23 :8979- 8986.

- Delmas D, Jannin B and Latruffe N (2005) Resveratrol preventing properties against vascular alterations and ageing. Mol Nutr Food Res. 49:377-395.

- Delmas D, Lancon A, Colin D, Jannin B and Latruffe N (2006) Resveratrol as a chemopreventive agent: a promising molecule for fighting cancer. Curr Drug Target 7:423-442.

- Hebbar V, Shen G, Hu R, Kim BR, Chen C, Korytko PJ, Crowell JA, Levine BS and Kong AN. (2005) Toxicogenomics of resveratrol in rat liver. Life Sci 76:2299-2314.

- Henry C, Vitrac X, Decendit A, Ennamany R, Krisa S and Merillon JM (2005) Cellular uptake and efflux of trans-piceid and its aglycone trans-resveratrol on the apical membrane of human intestinal Caco-2 cells. J Agric Food Chem 53:798-803.

- Kaldas MI, Walle UK and Walle T (2003) Resveratrol transport and metabolism by human intestinal Caco-2 cells. J Pharm Pharmacol 55:307-312.

- Lançon A, Delmas D, Osman H, Thénot J-P, Jannin B and Latruffe N (2004) Human hepatic cell uptake of resveratrol: involvement of both passived diffusion and carriermediated process. Biochem Biophys Res Commun 316:1132-1137. 
- Marier JF, Vachon P, Gritsas A, Zhang J, Moreau JP and Ducharme MP (2002) Metabolism and disposition of resveratrol in rats: extent of absorption, glucuronidation, and enterohepatic recirculation evidenced by a linked-rat model. $J$ Pharmacol Exp Ther 302:369-373.

- Miksits M, Maier-Salamo A, Aust S, Thalhammer T, Teznicek G, Kunert O, Haslinger E, Szeleres T and Jaeger X (2005) Sulfation of resveratrol in human liver : evidence of a major role for the sulfotransferases SULT1A1 and SULT1E1. Xenobiotica 35 :11011119.

- Pfaffl MW, Horgan GW and Dempfle L (2002) Relative expression software tool (REST) for groupe-wise comparison and statistical analysis of relative expression results in real-time PCR. Nucleic Acids Res 30:e36.

- Sergent T, Garsou S, Schaut A, De Saeger S, Pussemier L, Van Peteghem C, Larondelle Y and Schneider YJ (2005) Differential modulation of ochratoxin A absorption across Caco-2 cells by dietary polyphenols, used at realistic intestinal concentrations. Toxicol Lett 159:60-70.

- Vitaglione P, Sforza S, Galaverna G, Ghidini C, Caporaso N, Vescovi PP, Fogliano V and Marchelli R (2005) Bioavailability of trans-resveratrol from red wine in humans. Mol Nut Food Res 49:495-504.

- Walle T, Hsieh F, DeLegge MH, Oatis JE Jr and Walle UK (2004) High absorption but very low bioavailability of oral resveratrol in humans. Drug Metab Dispos 32:13771382.

- Wenzel E and Somoza V (2005) Metabolism and bioavailbility of trans-resveratrol. Mol Nut. Food Res 49: 472-481.

- Wenzel E, Soldo T, Erbersdobler H and Somoza V (2005) Bioactivity and metabolism of trans-resveratrol orally administered to Wistar rats. Mol Nut Food Res 49:482-494.

- Zhu Z, Klironomos G, Vachereau A, Neirinck L and Goodman DW (1999) Determination of trans-resveratrol in human plasma by high-performance liquid chromatography. J Chromatogr B Biomed Sci Appl.724:389-392

\section{FOOTNOTES}

This study was supported by the "Conseil Régional de Bourgogne", BIVB and the "Ligue Bourguignonne contre le Cancer". 


\section{FIGURES \& TABLE}

A

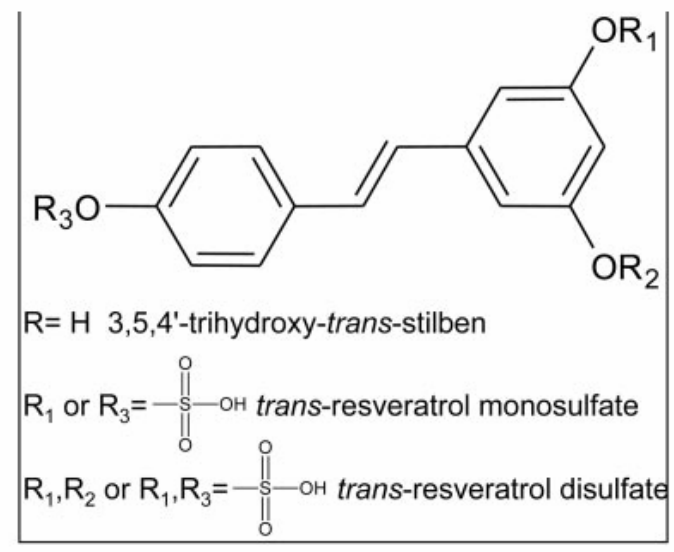

B
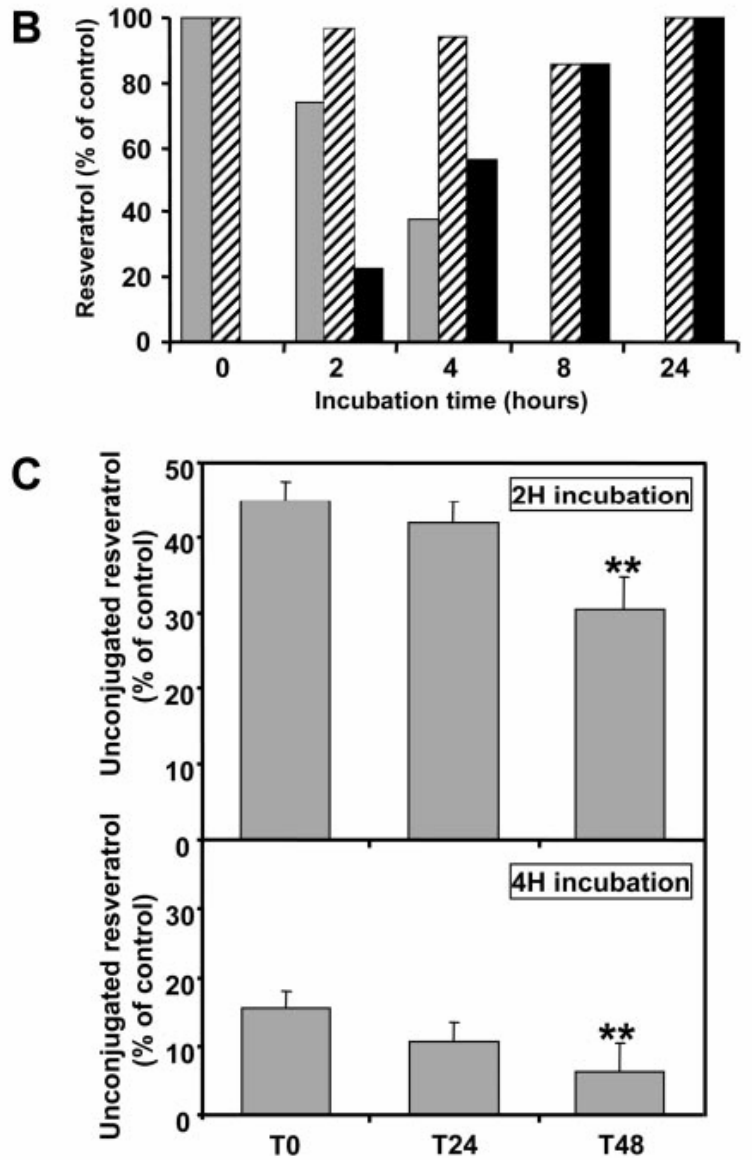

FIG. 1. Resveratrol metabolism: time course and autoinduction. A, chemical structure of resveratrol and resveratrol sulfates; $B$, time course of conjugation. HepG2 cells were treated for the indicated times with $10 \mu \mathrm{M}$ resveratrol. Collected culture media were extracted and analyzed by HPLC. They were treated either at $37^{\circ} \mathrm{C}$ for $1 \mathrm{~h}$ with $\beta$-glucuronidase for the quantification of total resveratrol (striped bar) or with buffer alone for the quantification of unconjugated resveratrol (gray bar). The difference between these two values gave the percentage of conjugated resveratrol (black bar). C, autoinduction of resveratrol metabolism. HepG2 cells were pretreated for $0 \mathrm{~h}$ (T0), $24 \mathrm{~h}$ (T24), or $48 \mathrm{~h}$ (T48) with $10 \mu \mathrm{M}$ resveratrol. Cell culture media were discarded and the cells were exposed again to $10 \mu \mathrm{M}$ resveratrol for $2 \mathrm{~h}$ (top) or $4 \mathrm{~h}$ (bottom). The amount of unconjugated resveratrol was determined by HPLC and expressed as percentage of the amount of resveratrol added to medium at the beginning of the incubations. Values represent the mean \pm S.D. of triplicate samples from two individual experiments (* corresponds to $p<0.05$, *** to $p<$ 0.01 , and $* * * *$ to $p<0.001$ ). 
A

mRNA level fold induction

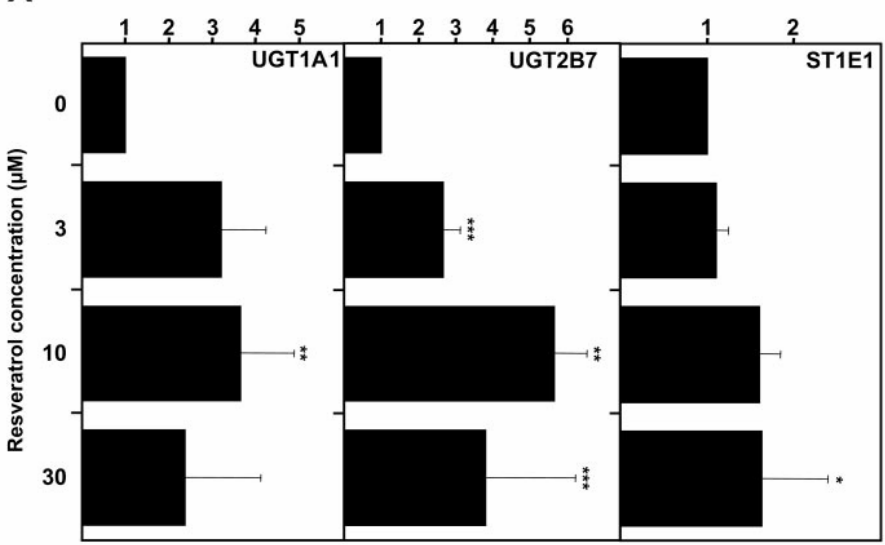

FIG. 2. Resveratrol induces phase II enzyme expression in human hepatoblastoma cells. A HepG2 cells were either untreated or treated with the indicated concentrations (micromolar) of resveratrol during $24 \mathrm{~h}$ of treatment. Real-time PCR shows mRNA level of UGT1A1, UGT2B7, and ST1E1 in HepG2 cells. Bars represent the increase in HepG2 cells as a -fold change of control (*, $p<0.05 ; * *, p<0.01 ; * * *, p<0.001)$. B, flow cytometry analysis of UGT1A1, UGT2B7, and ST1E1 expression in HepG2 cells untreated (black line) or treated (gray line), under the same conditions as in A. with $10 \mu \mathrm{M}$ resveratrol ( $\mathrm{R} 10$ ) or $30 \mu \mathrm{M}$ resveratrol ( $\mathrm{R} 30$ ) for the indicated time. The percentages represent the relative increase in expression compared with control One representative of three independent experiments is R10
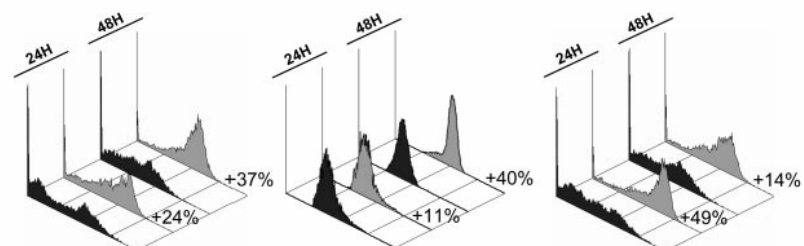
shown.

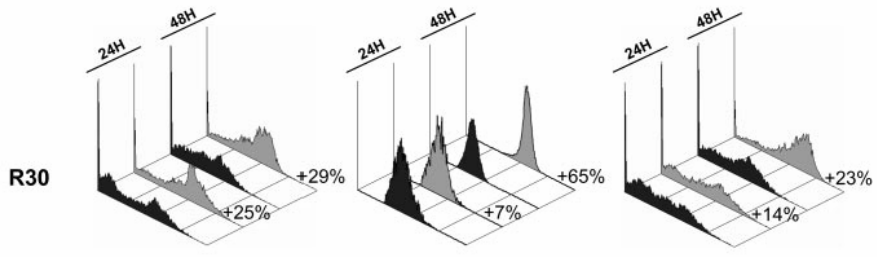

UGT1A1

UGT2B7

ST1E

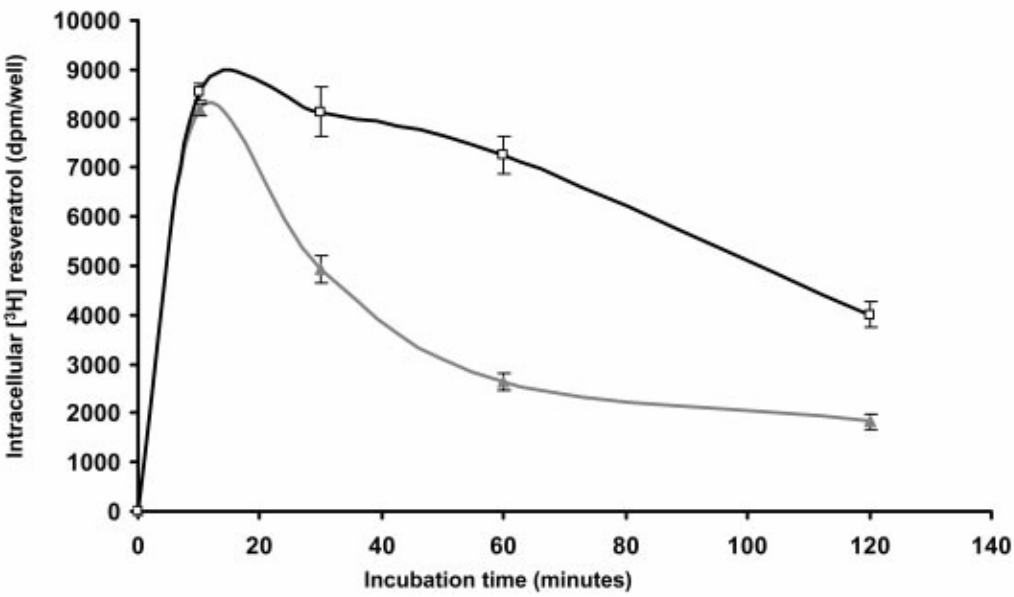

Fig. 3. Inhibition of resveratrol efflux by $\mathrm{MK} 571$. HepG2 cells were incubated in the presence of $1 \mu \mathrm{M}$ labeled resveratrol (specific activity $3.7 \mathrm{GBq} / \mathrm{mmol}$ ) at $37^{\circ} \mathrm{C}$ for the indicated times, in the absence (gray triangles) or presence (open squares) of $50 \mu \mathrm{M} M K 571$. At the end of each incubation period, the labeled medium was removed and after fast washing and cell lysis, the amount of resveratrol remaining in the cells was evaluated from the cell-associated radioactivity determined by counting in a liquid scintillation analyzer. Data points are from a representative experiment among three, and each point represents the mean of two determinations. 
TABLE 1

Negative ion atmospheric pressure chemical ionization-tandem muss spectrometry on resveratrol metabolites The numbers in parentheses indicate the relative intensity.

\begin{tabular}{|c|c|c|c|c|}
\hline \multirow{2}{*}{$\begin{array}{l}\text { MS1 Ions }(m f z) \\
{[\mathbf{M}-\mathbf{H}]^{j-2}}\end{array}$} & \multicolumn{2}{|c|}{ MS2 Product Ions } & \multirow{2}{*}{ MS3 Product Ions (miz) } & \multirow{2}{*}{ Identification } \\
\hline & $m+2$ & Fragment loss & & \\
\hline 227 & $\begin{array}{l}185(100) \\
159(48) \\
143(27) \\
185(100)\end{array}$ & $\begin{array}{l}{[\mathrm{M}-\mathrm{H}-42]^{-}} \\
{[\mathrm{M} \cdots \mathrm{H}-68]^{-}} \\
{[\mathrm{M} \cdots \mathrm{H}-84]^{-}} \\
{[\mathrm{M} \cdots \mathrm{H}-42]^{-}}\end{array}$ & & (Standard resveratrol) \\
\hline 227 & $\begin{array}{l}159(48) \\
143(27) \\
243(8)\end{array}$ & $\begin{array}{l}{[\mathrm{M}-\mathrm{H}-68]^{-}} \\
{[\mathrm{M}-\mathrm{H}-84]^{-}} \\
{[\mathrm{M}-\mathrm{H}-64]^{-}}\end{array}$ & & Resveratrol \\
\hline 307 & $\begin{array}{l}227(100) \\
265(100)\end{array}$ & $\begin{array}{l}{[\mathrm{M}-\mathrm{H}-80]^{-}} \\
{[\mathrm{M}-\mathrm{H}-64]^{-}}\end{array}$ & $185,159,143$ & Resveratrol monosulfate \\
\hline 329 & $\begin{array}{l}249(60) \\
242(72) \\
345(11)\end{array}$ & $\begin{array}{l}{[M-H-80]^{-}} \\
{[M-H-64-23]^{-}} \\
{[M-H-64]^{-}}\end{array}$ & & Sodium resveratrol monosulfate \\
\hline 409 & $\begin{array}{l}329(100) \\
306(12)\end{array}$ & $\begin{array}{l}{[\mathrm{M}-\mathrm{H}-80]^{-}} \\
{[\mathrm{M}-\mathrm{H}-80-23]^{-}}\end{array}$ & $265,249,242$ & Sodium resveratrol disulfate \\
\hline
\end{tabular}

